\title{
ハイブリッド形ステッピングモータの 高調波トルクの低減法
}

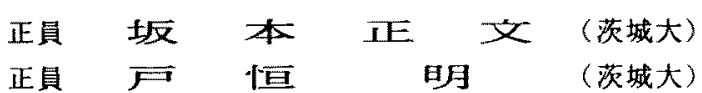

\begin{abstract}
A Method of Correction of Torque Harmonics in Hybrid Stepping Motor
\end{abstract} Masaf umi Sakamoto, Member, Akira Tozune, Member (Ibaraki University)

\begin{abstract}
One of the causes of characteristic deterioration and generation of vibration in hybrid stepping motor is the harmonic component flux contained in the field flux. In this paper, a wethod is described for reducing harmonic components by using a rotor consisted of two sets of rotor which is commonly used in hybrid stepping motors of comparatively large output. A trial of reducing harmonic is made by using such a type of rotor whose two component rotors are arranged on a shaft to give some angular displace ment in order to get some phase shift between flux distribution of their magnets. Through the experiment on various sample motors, it was confirmed that this method is fairly effective in decreasing the harmo nic components to improve the characteistic of stepping motors both in full-step operation and microstep operation.
\end{abstract}

キーワート：ステッピングモータ，ハイブリッドステッピングモータ，空間高調波，高調波トルク，振動

\section{1.まえがき}

回転子に永久磁石をもったハイブリッド形ステッピング モータは高分解能性を有し、位置決め用として、また可変 速同期アクチュエータとして、OA機器や工作機械等に広 く用いられている。

近年、ステッピングモータに対しては通常特性の更なる 向上の他に駆動時に発生する振動や回転むらに対する低減 要求もなされてきている。ハイブリッド形ステッピングモ 一タの特性悪化や振動発生をもたらす原因の一つに界磁磁 東分布が正弦波とならず高調波分を含むことがあげられる。 界磁束分布の特性への影留に関しては、これまでにも

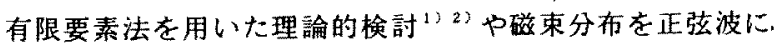

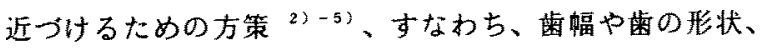
さらにはバーニヤスロット法などの構造的な娭誩がなされ た。しかしながら、いずれの方法も特性全般を満足させる には十分てないようである。

そこで本文では、新たに界磁磁束の高調波分を低減させ る一つの方法、すなわち、通常のハイブリッド形ステッピ ングモー夕の回転子と同一の回転子を 2 組有するような構 造の回転子（現在比僌的出力の大きなハイブリッド形ステ ッピングモータに用いられている）を利用して界磁磁束の 高調波分を低減する方法を提案ずると共に、本方法により どの程度特性改善が計れるかを検討する627。
すなわち、ステッピングモータは通常のフルステップ駆 動の他に分解能の向上や振動、䮣音の低隇のためにマイク ロスッテプ㤉動屯行われるので両駆動時における本方法に よる特性改善効果について険討する。

\section{2、空間高調波の特性に及ほす影㫪}

ますこここで、図1に示すハイブリッド形ステッピングモ 一夕の界磁磁束に高調波分が含まれるときの、その特性に 及ぼす影響について検討する。すなわち、高調波分の（i） トルク一角度特性および(ii)フルステップ駆動時並びに マイクロステップ眍動時の振動トルクに及ぼす影響を理諭 的に考察しておく。

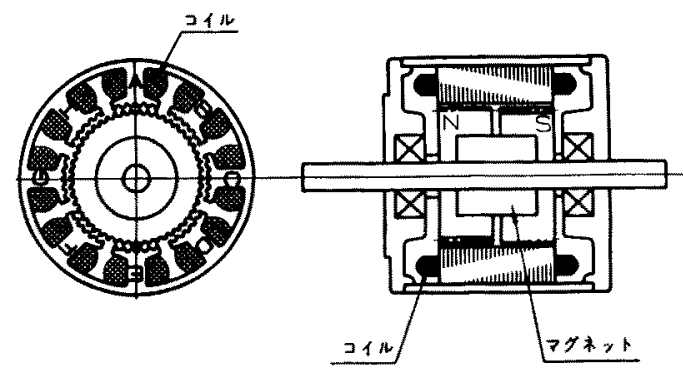

图1、ハイブリット形スデッピングモータの構造図 Fig. 1 Constrution of a hybrid stepping motor. 
〈2・1〉トルクー角度特性への影整 トルク一角 度特性を決定するトルク成分としては、(1)界磁磁束と巻線 電流に基ずくトルク（I B L 則に基ずくトルク）、(2)リラ クタンストルク、(3)ティテントトルクが考えられるが、リ ラクタンストルクは一般に小さく考虑されない場合が多い 4)。そこで、ここでは界磁磁束の高調波分によって I B L 則に基ずくトルク並びにテイテントトルクがどのような影 製を受けるかを検討する。

〈2・1・1〉 | BL則に基つくトルク 固定子磁 極 A（図 1 ）の中央の蔽の中心線から回転子歯の中央まで の角 $\theta$ (機械角) を図 2 のようにとると、 $\mathrm{A}$ 相巻線に鎖交 する回転子からの空隙磁束密度 B。( $(\theta)$ は奇数次調波のみ から成り

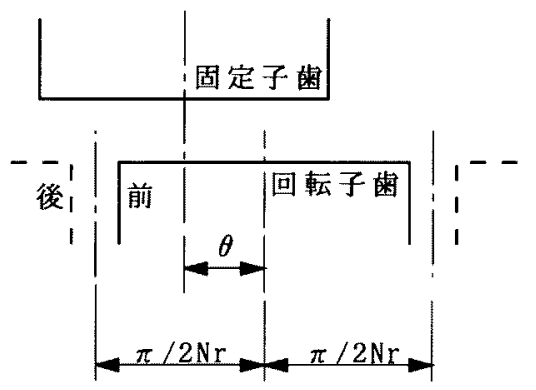

図 2. 固定子と回転子歯の変位角

Fig. 2 Displacement angle between stator and rotor teeth

$\mathrm{B}_{\mathrm{a}}(\theta)=-\mathrm{B}_{\mathrm{m}}\left(\sin \mathrm{N}_{\mathrm{r}} \theta+\mathrm{k}_{3} \sin 3 \mathrm{~N}_{\mathrm{r}} \theta+\mathrm{k}_{5} \sin 5 \mathrm{~N}_{\mathrm{r}} \theta\right.$ $\left.+\mathrm{k}_{7} \sin 7 \mathrm{~N}_{5} \theta+\cdots\right)$

と表せる。

$\mathrm{B}_{\mathrm{m}}$ ：基本波の最大磁束密度、 $\mathrm{N}_{\mathrm{r}}$ : 回転子歯数、

$\mathrm{k}_{\mathrm{q}}$ : 基本波分に対する q 次調波分の振幅比、磁

束の向き：回転子から出る磁束を正

回転子の菌幅が $\pi / N_{\mathrm{r}}$ でない場合には(1)式のB。( $\left.\theta\right)$ を 補正する必要があり、次式のようになる

$\mathrm{B}_{\mathrm{a}}(\theta)=-\mathrm{B}_{\mathrm{m}}\left(\varepsilon_{\mathrm{SI}} \sin \mathrm{N}_{\mathrm{r}} \theta+\varepsilon_{\mathrm{S}} \mathrm{k}_{3} \sin 3 \mathrm{~N}_{\mathrm{r}} \theta\right.$

$\left.+\varepsilon_{S 5} k_{5} \sin 5 N_{r} \theta+\varepsilon_{S 7} k_{7} \sin 7 \mathrm{~N}_{\mathrm{r}} \theta+\cdots\right)$

ただし $\quad \boldsymbol{e}_{\mathrm{sq}}=\cos \left\{\mathrm{q}\left(\pi / 2-\mathrm{N}_{\mathrm{r}} \theta_{1}\right)\right\}$

ここに $\mathrm{q}:$ 高調波の次数、 $\theta_{1}:$ 固定子歯幅の $1 / 2$

の角度 巻線に直流電流 I を流したときに発生す

るトルクの大きさ $\mathrm{T} F$ 政 $\mathrm{B} \mathrm{L}$ 則に基ついて

$$
\begin{aligned}
\mathrm{T}_{\mathrm{F}}= & \mathrm{KIB}_{\mathrm{a}}(\theta) \quad(\mathrm{K} \text { は定数) } \\
= & \mathrm{KIB}_{\mathrm{m}}\left(\boldsymbol{\varepsilon}_{\mathrm{s}} \mathrm{sinN}_{\mathrm{r}} \theta+\varepsilon_{\mathrm{s} 3} \mathrm{~K}_{9} \sin 3 \mathrm{~N}_{\mathrm{r}} \theta\right. \\
& \left.+\varepsilon_{\mathrm{s} 5} \mathrm{k}_{5} \sin 5 \mathrm{~N}_{\mathrm{r}} \theta+\varepsilon_{\mathrm{s} 7} \mathrm{~K}_{7} \sin 7 \mathrm{~N}_{\mathrm{r}} \theta+\cdots\right)
\end{aligned}
$$

と与えられる。

(2)式と (4)式の比較から、このトルクの形状は磁束密 度分布波形と同一になることがわかる。

〈2・1・2〉 ティテントトルク ティテントトル クはエアギャップの不均一性（非真円や偏心等）や固定子 および回転子が菌をもつこと等によるギャップ磁束の非正
弦波分布によって生ずるが、ここではティテントトルクの 大部分を占めるギャップ磁束の非正弦波分布に基つくトル ク成分について考える゙。

ハイブリッド形ステッピングモータの回転子は図 1 のよ うに前倒と後万側の 2 段に分かれており、巻線電流を流さ ないときの前側のみの等価磁気回路は図 3 のように表せる。

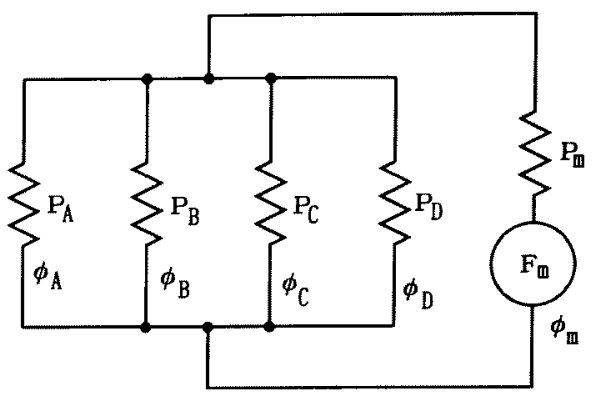

図 3. 磁気等価回路

Fig. 3 Magnetic equivalent circuit

このとき、各固定子磁極を通るマグネット磁束は図 3 から それぞれ、

$$
\left.\begin{array}{lll}
\phi_{\mathrm{A}} \fallingdotseq \frac{\mathrm{P}_{\mathrm{m}} \mathrm{F}_{\mathrm{m}}}{4 \mathrm{P}_{0}} \mathrm{P}_{\mathrm{A}} & , & \phi_{\mathrm{B}} \fallingdotseq \frac{\mathrm{P}_{\mathrm{m}} \mathrm{F}_{\mathrm{m}}}{4 \mathrm{P}_{0}} \mathrm{P}_{\mathrm{B}} \\
\phi_{\mathrm{C}} \fallingdotseq \frac{\mathrm{P}_{\mathrm{m}} \mathrm{F}_{\mathrm{m}}}{4 \mathrm{P}_{0}} \mathrm{P}_{\mathrm{C}} & , & \phi_{\mathrm{D}} \fallingdotseq \frac{\mathrm{P}_{\mathrm{m}} \mathrm{F}_{\mathrm{m}}}{4 \mathrm{P}_{0}} \mathrm{P}_{\mathrm{D}}
\end{array}\right\}
$$

と表される。

いま、 $\mathrm{A} 、 \mathrm{~B} ， \mathrm{C} ， \mathrm{D}$ 極の前側のギャップパーミアンス $P_{A} 、 P_{B}, P_{C}, P_{D}$ をそれぞれ、

$$
\begin{aligned}
\mathrm{P}_{\mathrm{A}} & =\mathrm{P}_{0}\left(1+\nu_{1} \cos \mathrm{N}_{\mathrm{r}} \theta+\nu_{2} \cos 2 \mathrm{~N}_{\mathrm{r}} \theta+\nu_{3} \cos 3 \mathrm{~N}_{\mathrm{r}} \theta+\cdots\right) \\
\mathrm{P}_{\mathrm{B}}= & \mathrm{P}_{0}\left\{1+\nu_{1} \cos \left(\mathrm{N}_{\mathrm{r}} \theta-\pi / 2\right)+\nu_{2} \cos 2\left(\mathrm{~N}_{\mathrm{r}} \theta-\pi / 2\right)\right. \\
& \left.+\nu_{3} \cos 3\left(\mathrm{~N}_{\mathrm{r}} \theta-\pi / 2\right)+\cdots\right\} \\
\mathrm{P}_{\mathrm{C}} & =\mathrm{P}_{0}\left\{1+\nu_{1} \cos \left(\mathrm{N}_{\mathrm{r}} \theta-\pi\right)+\nu_{2} \cos 2\left(\mathrm{~N}_{\mathrm{r}} \theta-\pi\right)\right. \\
& \left.+\nu_{3} \cos 3\left(\mathrm{~N}_{\mathrm{r}} \theta-\pi\right)+\cdots\right\} \\
\mathrm{P}_{\mathrm{D}}= & \mathrm{P}_{0}\left\{1+\nu_{1} \cos \left(\mathrm{N}_{\mathrm{r}} \theta-3 \pi / 2\right)+\nu_{2} \cos 2\left(\mathrm{~N}_{\mathrm{r}} \theta-3 \pi / 2\right)\right. \\
& \left.+\nu_{3} \cos 3\left(\mathrm{~N}_{\mathrm{r}} \theta-3 \pi / 2\right)+\cdots\right\}
\end{aligned}
$$

とおくと、磁極 $\mathrm{A}$ の前側に発生するトルクTDA磁気工 ネルギーの角度による変化として求められ次のようになる。

$$
\begin{aligned}
\mathrm{T}_{\mathrm{DA}} & =-\frac{1}{2} \frac{\partial}{\partial \theta}\left\{\phi_{A}{ }^{2} \cdot\left(\frac{1}{\mathrm{P}_{\mathrm{A}}}\right)\right\} \\
& =-\frac{\mathrm{N}_{\mathrm{r}} \mathrm{P}_{\mathrm{m}}{ }^{2} \mathrm{~F}_{\mathrm{m}}{ }^{2}}{32 \mathrm{P}_{0}}\left(u \sin \mathrm{N}_{\mathrm{r}} \theta+2 \nu_{2} \sin 2 \mathrm{~N}_{\mathrm{s}} \theta+3 \nu_{\mathrm{s}} \sin 3 \mathrm{~N}_{\mathrm{r}} \theta+\cdots\right)
\end{aligned}
$$

同様にして、磁極 $\mathrm{A}$ からHまでの前側、後ろ側について それぞれティテントトルクを求め、これらを加え合わせる ことによって全体のティテントトルクの大きさ $\mathrm{T}$ 。を求め ると

$$
\mathrm{T}_{\mathrm{D}}=\frac{\mathrm{N}_{\mathrm{r}} \mathrm{P}_{\mathrm{m}}{ }^{2} \mathrm{~F}_{\mathrm{m}}^{2}}{\mathrm{P}_{0}}\left(\nu_{4} \sin 4 \mathrm{~N}_{\mathrm{r}} \theta+2 \nu_{8} \sin 8 \mathrm{~N}_{\mathrm{r}} \theta+\cdots\right)
$$

となる。(8)式からわかるように、デイテントトルクは全 
体としては 4 の整数倍調波分のトルクのみが現れることに なる。

〈2・2〉 フルステッフ国㖵時の振動トルクへの影䜿

2 相励磁で定電流駆動した場合の発生トルクについて考 祭する。

A 相、B相巻線への回転子マグネットからの鎖交磁束 $\lambda_{\mathrm{A}}(\theta) 、 \lambda_{\mathrm{B}}(\theta)$ はそれぞれ、

$$
\begin{aligned}
& \lambda_{\mathrm{A}}(\theta)=\sum \lambda_{2 \mathrm{~m}+1} \cos \left\{(2 \mathrm{~m}+1)\left(\mathrm{N}_{\mathrm{r}} \theta\right)\right\} \\
& \lambda_{\mathrm{B}}\left(\mathrm{N}_{\mathrm{r}} \theta\right)=\sum \lambda_{2 \mathrm{~m}+1} \cos \left\{(2 \mathbb{M}+1)\left(\mathrm{N}_{\mathrm{r}} \theta-\pi / 2\right)\right\}
\end{aligned}
$$
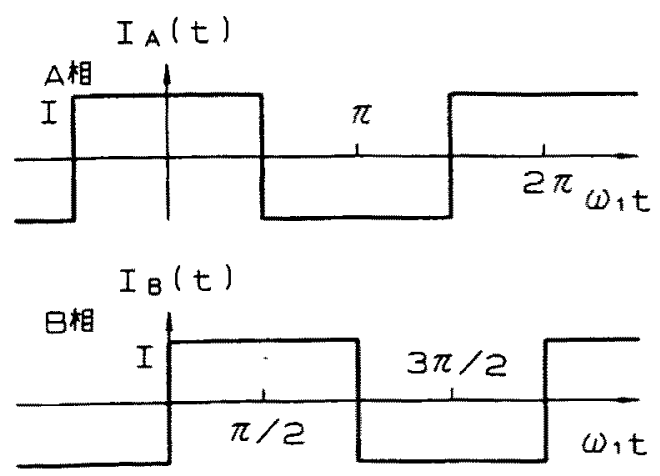

図 4.2 相励磁時の電流波形

Fig. 4 Applied phase current waveform for two phase operation.

\section{と与えられる。( $\mathrm{m}: 0.1,2, \cdots)$}

また耐相巻線に流す電流を図 4 のような振幅 I の矩形波 とすると、A 相、B相の電流I、IBはフーリ工級数展開 によりをれぞれ、

$$
\begin{aligned}
& I_{A}=\frac{4 I}{\pi} \sum_{0}^{B} \frac{1}{(2 n+1)} \cos (2 n+1) \omega_{1} t \\
& I_{B}=\frac{4 I}{\pi} \sum_{0}^{n} \frac{1}{(2 n+1)} \cos (2 n+1)\left(\omega_{1} t-\frac{\pi}{2}\right)
\end{aligned}
$$

と表される。( $\mathrm{n}: 0.1 .2, \cdots)$

いま、回転子が一定角速度 $\omega_{1}$ (電気角速度)で回軽

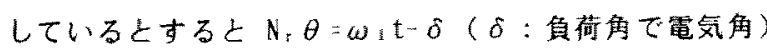
と書けるから、A相、B相による発生トルク $\mathrm{T}_{\mathrm{A}} 、 \mathrm{~T}_{\mathrm{B}}$ は、 一相当りの有効巻数を $\mathrm{N}$ とすると、それそれれ

$$
\begin{aligned}
& T_{A}=I_{A} \frac{d \lambda_{A}}{d \theta}=-\frac{4 N I}{\pi} \sum_{i}^{n} \frac{1}{(2 n+1)} \cos (2 n+1) \omega_{1} t \\
& \times\left\{\sum_{d}^{n}(2 m+1) \lambda_{2 m+1} \sin (2 m+1) N_{r} \theta\right\} \\
& T_{B}=I_{B} \frac{d \lambda_{B}}{d \theta}=-\frac{4 N I}{\pi} \sum_{0}^{n} \frac{1}{(2 n+1)} \cos (2 n+1)\left(\omega, t-\frac{\pi}{2}\right) \\
& \times\left\{\sum_{\sigma}^{\infty}(2 m+1) \lambda_{2 m+3} \sin (2 m+1)\left(N_{r} \theta-\frac{\pi}{2}\right)\right\}
\end{aligned}
$$

として求められ、A相、B相による合成トルクT、は

$$
\begin{aligned}
T_{T} & =\frac{4 N I}{\pi}\left[\left(\lambda_{1} \sin \delta+(1 / 3) \sin 3 \delta+(1 / 5) \sin 5 \delta+\cdots\right\}\right. \\
& -\left(3 \lambda_{3} \sin \left(4 \omega_{1} \mathrm{t}-3 \delta\right)+5 \lambda_{5} \sin \left(4 \omega_{1} \mathrm{t}-5 \delta\right)+\cdots\right\} \\
& -(1 / 3)\left\{\lambda_{1} \sin \left(4 \omega_{1} \mathrm{t}-\delta\right)+5 \lambda_{5} \sin \left(8 \omega_{1} \mathrm{t}-5 \delta\right)+\cdots\right\} \\
& +(1 / 5)\left\{\lambda_{1} \sin \left(4 \omega_{1} \mathrm{t}-\delta\right)-3 \lambda_{3} \sin \left(8 \omega_{1} \mathrm{t}-3 \delta\right)+\cdots\right\} \\
& +\cdots]
\end{aligned}
$$

(12)式の第1行目は電流と界磁磁束の同一次数調波成分同 志加作用して発生する平均卜ル夕、第 2 行目、第3 行目、 4 行目・・は虬ぞれ、電流の基本波分、第3 謂波分、 第 5 調波分・..が果磁磁束と作用して発生する振動トル クを表す。(12)式から、振動トルクは電流周波数の4の整 数倍の周波数をもつこと、振動トル夕は主に基本波份電流

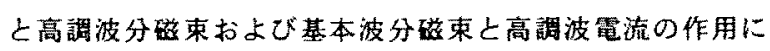
上って発生することがわかる。したがって、高調波分磁束

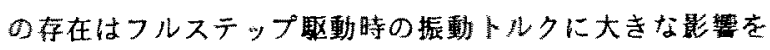
及话すことになる。

〈2・3〉 マイクロステッブ趿時の振動トルクへの 影整 マイクロステップ舸動の分割数を增加したとき の電流波形は正弦波に近つくため、正弦波 2 相交流か、A 頛およびB相に䁒加された場合の登生トルクについて考察 する。

$\mathrm{A}$ 相、B相の電流を次式の上うに与える。

$$
\begin{aligned}
& I_{A}=I_{m} \cos (\omega t+\alpha) \\
& I_{B}=I_{m} \sin (\omega t+\alpha)
\end{aligned}
$$

I BL 則による発生トルクTッは

$T_{M}=K I_{\text {tin }}\left(B_{a}(\theta) \cos (\omega t+\alpha)\right.$

$$
\left.+\mathrm{B}_{\mathrm{a}}\left(\theta-\pi / 2 \mathrm{~N}_{\mathrm{r}}\right) \sin (\omega \mathrm{t}+\alpha)\right\}
$$

と表せるため(2)式を( 14 年式に代入して

$T_{M}=K I_{m} B_{m}\left(\varepsilon_{s}, \sin \left(\omega t+\alpha-N_{r} \theta\right)-\varepsilon_{s 3} k_{3} \sin (\omega t\right.$ $\left.+\alpha+3 N_{r} \theta\right)+\varepsilon_{S 5} k_{5} \sin \left(\omega t+\alpha-5 N_{r} \theta\right)$ $\left.-\varepsilon_{S 7} k_{7} \sin \left(\omega t+\alpha+7 N_{r} \theta\right)+\cdots\right)$

となる。

いま、回転子が同期速度 $\omega$ で回転しているとして $\mathrm{N}, \theta=\omega t-\delta$ とおくと、T $\mathrm{T}$

$$
\begin{aligned}
\mathrm{T}_{M}= & K I_{\mathrm{m}} B_{\mathrm{m}}\left(\varepsilon_{\mathrm{S} 1} \sin (\delta+\alpha)-\varepsilon_{\mathrm{S} 3} \mathrm{k}_{3} \sin (4 \omega \mathrm{t}+\alpha\right. \\
& -3 \delta)-\varepsilon_{\mathrm{S}} \mathrm{k}_{5} \sin (4 \omega \mathrm{t}-\alpha+5 \delta) \\
& \left.-\varepsilon_{57} \mathrm{k}_{7} \sin (8 \omega \mathrm{t}+\alpha-7 \delta)+\cdots\right\}
\end{aligned}
$$

となる。

(16)式からわかるように、正弦波電流で驟動した場合に は一定トルクの他に界磁磁束の奇数次諨波分に基ついて笔 溹周波数の4 整数倍の周波数をもつ振動トルクが発生する ことになる。

\section{3、高調波の低減法}

現在、比較的出力の大きなハイブリッド形ステッピン グモータには、界磁磁束を高めるために、通常の回転子を 2組有するような構造の回転子が用いられている(図5)。 このような回転子を棈成する 2 租の回軽子の柬は、通常 図6(a)に示すように同極の蔽同志がそれぞれ一直線に並 


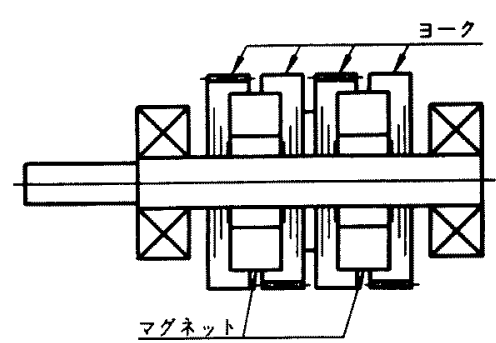

図 5, 供試電動機の回転子構造図

Fig. 5 Roter construction of sample motors.

ぶように配置されている。ここではこの 2 組の回転子を図 6(b)に示すように $\theta$ 。だけ角度をずらして配置し、図 7 に示すように両回転子による酳束密度分布の位相がある角 度ずれるようにして高調波磁束の減少を計ることを試みる。

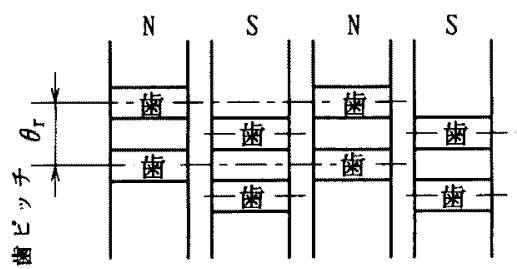

(a)

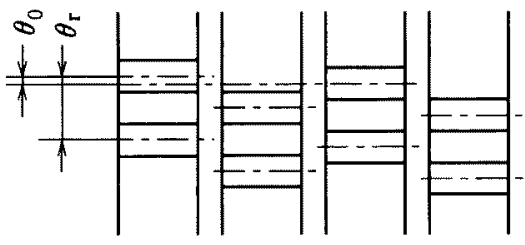

(b)

図 6.回転子の歯の配列図

Fig. 6 Roter teeth arrangements of sample moters.

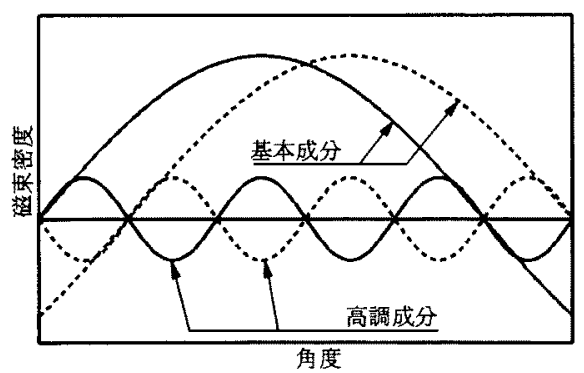

図 7. 高調波低減の原理図

Fig. 7 Principle of harmonic reduction

このとき、 2 組の回転子から一つの相巻線に鎖交する磁 束の磁束密度を $\mathrm{B}_{1}(\theta)$ とすると

$$
\begin{aligned}
& \mathrm{B}_{1}(\theta)=-\left(\mathrm{B}_{\mathrm{m}} / 2\right)\left[\left(\boldsymbol{e}_{\mathrm{s} 1} \sin \left(\mathrm{N}_{\mathrm{r}} \boldsymbol{\theta}-\mathrm{N}_{\mathrm{r}} \boldsymbol{\theta}_{0} / 2\right)+\boldsymbol{\varepsilon}_{\mathrm{s} 3} \mathrm{k}_{3}\right.\right. \\
& \left.x \sin 3\left(N_{r} \theta-N_{r} \theta_{0} / 2\right)+e_{s} k_{5} \sin 5\left(N_{r} \theta-N_{r} \theta_{0} / 2\right)+\cdots\right\} \\
& +\left(\varepsilon_{\mathrm{s}}, \sin \left(\mathrm{N}_{\mathrm{r}} \theta+\mathrm{N}_{\mathrm{r}} \theta_{0} / 2\right)+e_{\mathrm{s} 3} \mathrm{k}_{3} \sin 3\left(\mathrm{~N}_{\mathrm{r}} \theta+\right.\right. \\
& \left.\left.\left.N_{r} \theta_{0} / 2\right)+\varepsilon_{s} k_{s} \sin 5\left(N_{r} \theta+N_{r} \theta_{0} / 2\right)+\cdots\right\}\right]
\end{aligned}
$$

となる。

（1つの回転子による基本波の磁束密度の最大値を $\mathrm{B}_{\mathrm{m}} / 2$ と した)

$$
\begin{gathered}
\text { ここで } \mathrm{q} \text { 次高調波分に対して } \\
\varepsilon_{\mathrm{pq}}=\cos \left(\mathrm{q}\left(\mathrm{N}_{\mathrm{r}} \theta_{0}\right) / 2\right\}
\end{gathered}
$$

なる係数 $\varepsilon \rho a$ を定義すると(17)式は次式のように書き改 められる。

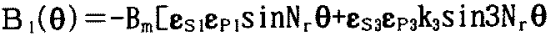

$$
\begin{aligned}
& \left.+\varepsilon_{S_{5}} \varepsilon_{P_{5}} \mathrm{k}_{5} \sin 5 \mathrm{~N}_{\mathrm{r}} \theta+\cdots\right]
\end{aligned}
$$

(18)式から $\theta$ 。による高調波含有量の変化を知ることが できる。例えば、N $\theta_{0}=\pi / 3 に$ 選ぶと第 3 調波は消える ことになる。

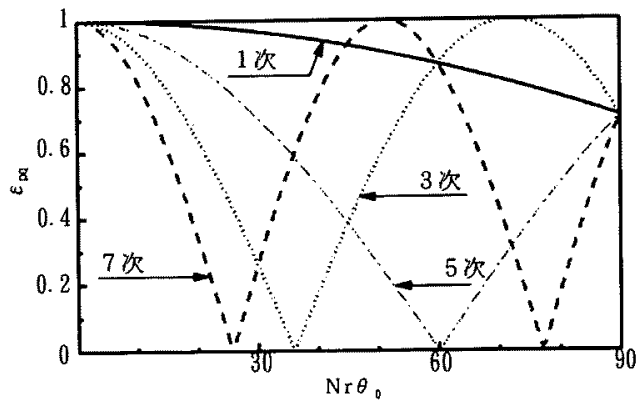

図 8.歯のずれ角による高調分の変化

Fig. 8 Amplitude variation of hamonic waves with $\mathrm{Nr} \theta_{0}$.

図 8 は q $=1 ， 3 ， 5 ， 7$ の場合について(18)式の関係 を示したものである。

同図から、仮に $N_{\mathrm{r}} \theta_{0}=\pi / 4$ となるような $\theta_{0}$ を選ふと すると第 3 調波と第 5 調波は 38.4 \%に減少するが基本波 は92.4\%となり、あまり隇少しないことがわかる。この ように、本方法によって、基本波成分の減少を少なく押さ えつつ高調波分を大幅に隇少させることができることがわ かる。

図 9 は本方式を適用して界磁磁束と巻線電流によるトル クの角度特性を改善する場合の計算例を示す。すなわち、同 図は (4) 式の磁束密度Ba（ $\theta)$ の代わりに(18)式を代入し、 種々のずれ角 $\theta$ 。に対してトルク一角度特性を求めたもの である。(ks=0.08 $\mathrm{k}_{5}=0.04 \varepsilon_{\mathrm{s}_{1}}=\varepsilon_{\mathrm{s}_{3}}=\varepsilon_{\mathrm{s}_{5}}=1$ とした。 $)$

この場合には同図に見ら扎るように $\mathrm{N}_{\mathrm{r}} \theta_{0}=\pi / 4$ に選ふ ことにより、トルクー角度特性の形状がかなり改善される ことがわかる。トルク一角度特性の形状を正弦波に近づけ ることによりマイクロステップ時の角度愦差も少なくする ことができると栲えられる。なお、図 9 のトルクは（4） 式中の K I B $\mathrm{m}$ との比で示した。 


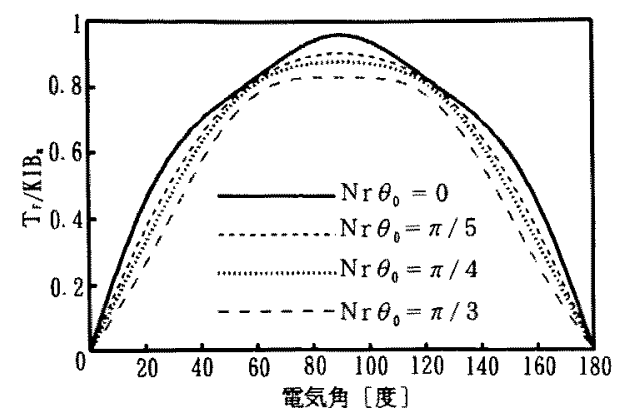

図 9、歯のずれ角のトルクー角度特性に及ぼす影響

Fig. 9 Variation of stiffness characteristics with $\mathrm{Nr} \theta_{0}$.

\section{4, 特性改善結果}

3 章で提案した高調波低減法によって、ステッピングモ 一タのフルステップ駆動時の特性やマイタロステップ販動 時の特性がどの程度改善されるかをN $\mathrm{r} \theta$ 。が $\pi / 3 、 \pi / 4 、$ $\pi / 5 、 0 の 4$ 璉の供試機を用いて、実験的に検討した。

$\langle 4-1\rangle$ フルステッブ取動時の特性 供試機の仕 様を表 1 に示す。表中の高調波含有率 $\mathrm{ks}$ 、k 5 はステッ ピングモー夕を外部から一定速度で回転させ、固定子巻線 に誘起する電压波形をF F Tにより周波数分析して求めた ものである。

表 1 ，供試機の定数

Table 1 Constans of sample motors.

\begin{tabular}{|c|c|c|c|c|}
\hline & $A$ & $B$ & $C$ & $D$ \\
\hline $\mathrm{Nr} \theta 0$ & 0 & $\pi / 3$ & $\pi / 4$ & $\pi / 5$ \\
\hline $\mathrm{Nr}$ & 50 & 50 & 50 & 50 \\
\hline$\varepsilon s 1$ & 0.977 & 0.977 & 0.977 & 0.977 \\
\hline$\varepsilon s 3$ & 0.801 & 0.801 & 0.801 & 0.801 \\
\hline$\varepsilon_{s} s$ & 0.481 & 0.481 & 0.481 & 0.481 \\
\hline $\mathrm{k}_{3}$ & 0.088 & 0.019 & 0.024 & 0.043 \\
\hline $\mathrm{k}_{5}$ & 0.024 & 0.025 & 0.015 & 0.004 \\
\hline
\end{tabular}

图 10 K $N_{r} \theta_{0}=0$ と $N_{r} \theta_{0}=\pi / 30$ ときの誘起電瓜波形

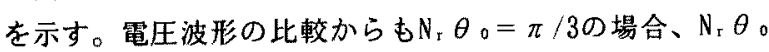
$=00$ とき比心高調波分が隇少していることが知られる。 图 11 は $N_{0} \theta_{0}=0$ とN $\theta_{0}=\pi / 3 の$ ときのトル夕一角度特

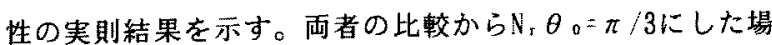
合、ステッフネス特性がかなり改善されることがかかる。 これは表1からわかるように、N、是。 0 (供試機 A)のとき には第 3 調波が多く含まれている( $\mathrm{k}_{3}$ が大きい)が、 $\mathrm{N}_{\mathrm{r}} \theta$ 。 $=\pi / 3$ (供試機 $\mathrm{B}$ )とすることにより第 3 調波が隇少したた
めと考えられる。

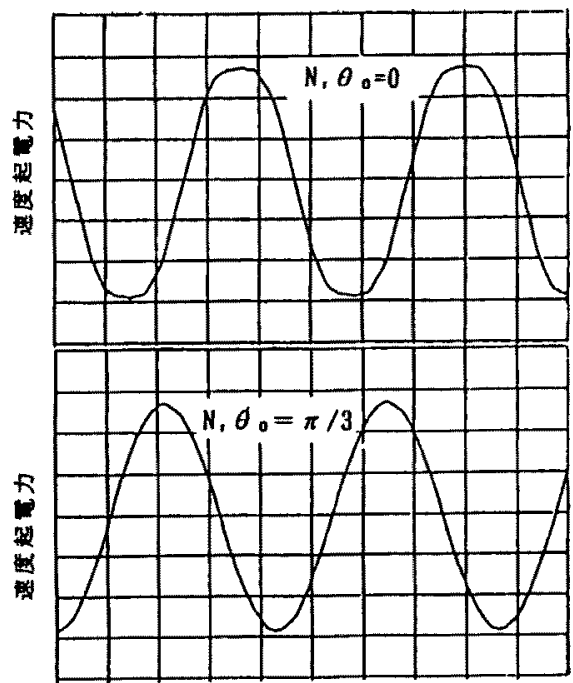

图 10 。誘起電圧波形

Fig. 10 Yeasured speed EMF waveform.
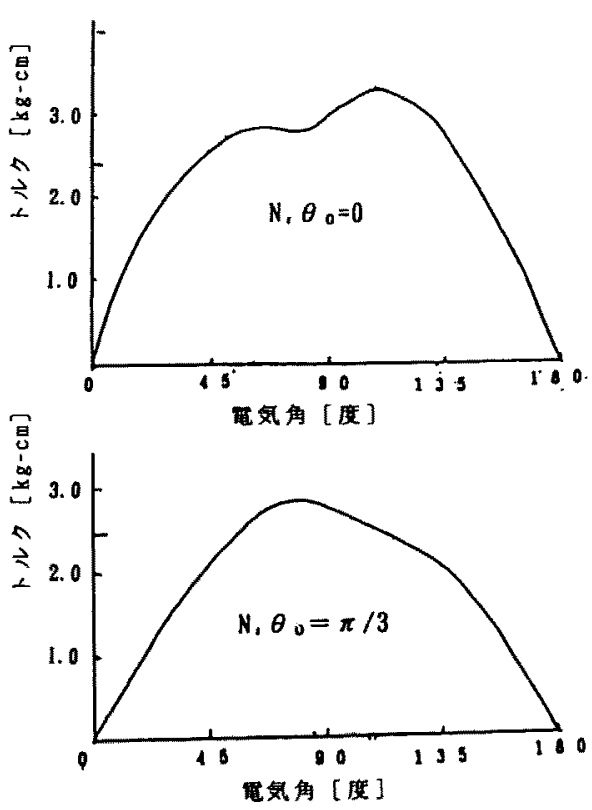

図11.トルク一角度特性の実測結果

Fig. 11 Experimental results of torque-angle characteristics.

なお、N，：=0のときのトルクの形状が図 9 の形状と異 なっているが、れは図11の奏測値の場合には図9のト ルク成分の他に主にテイテントトルク成分（図14）加加 わっているためと考えられる。

図 12 は脱出卜ルク特性について $\mathrm{N}_{\mathrm{r}} \theta_{0}=0$ の場合と $\mathrm{N}_{\mathrm{r}} \theta_{0}$ $=\pi / 3$ の場合とを比較して示したものである。同図にみら 


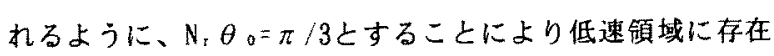
する共振特性がかなり改善されている。これはモー夕の共 振周波数之同一の周波数あるいはその整数倍の周波数を持

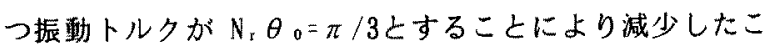
とが一つの理由と考えられる。

図 13 は 2 相励磁時におりる静止角度俱差を $N_{r} \theta_{0}=0$ と $N_{\mathrm{r}} \theta_{0}=\pi / 3$ 場合について比較したものである。同図には、 $N_{1} \theta_{0}=\pi / 3$ とすることにより、静止角度摆差が $1 / 2$ 以下に 隇少することが示されている。界磁磁束に高調波分が含ま れる場合には、基本波トルクのほかに高調波分トルタが発 生し、両者の和がゼロとなる位置で停止することになる。

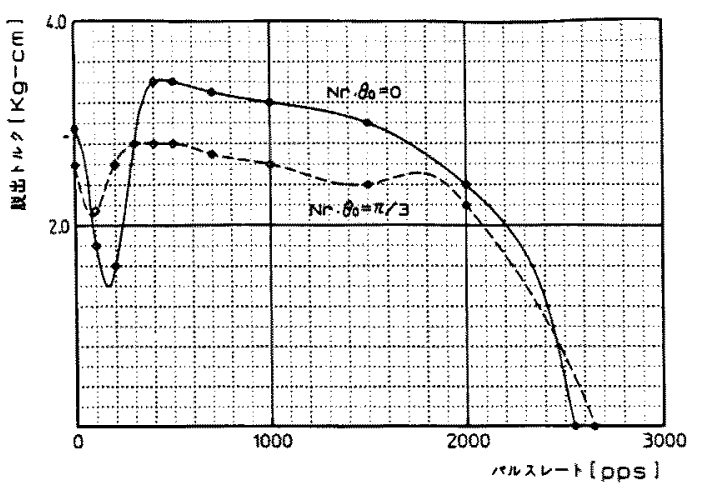

図 12 . 脱出トルクの実測データ

Fig. 12 Experimental results of pull-out characteristics.

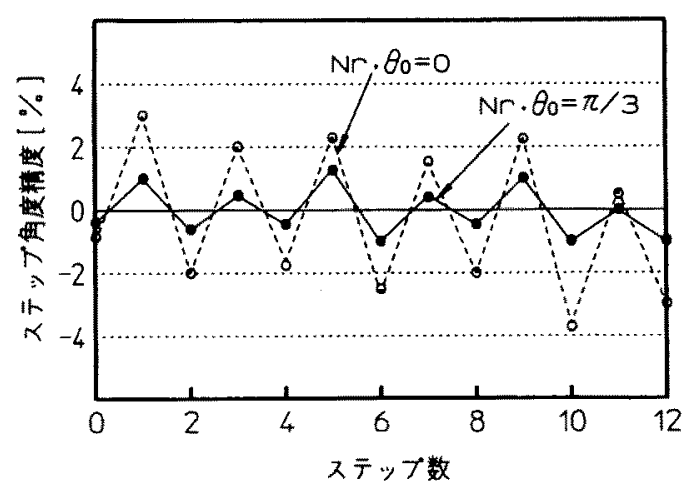

図 13 . 角度精度の実測結果

Fig. 13 Experimental results of position accuracy.

したがって、高調波磁束が含まれると基本波トルクがゼ ロとなる位置からはず机ることになり静止位置鿁差を生じ ることになる。図13の結果は、N、 $N_{0}=\pi / 3$ とすことに より、主に第3調波が隇少したためと考えられる。図14 はディテントトルクについての比較を示したものである。 同図からわかるようにティテントトルクも1/2以下に隇 少している。

图 15 は振動特性を $N_{\mathrm{r}} \theta_{0}=0$ 場合と $N_{\mathrm{r}} \theta_{0}=\pi / 30$ 場 合とを比較して示したものである。同図には $N_{0} \theta_{0}=\pi / 3$

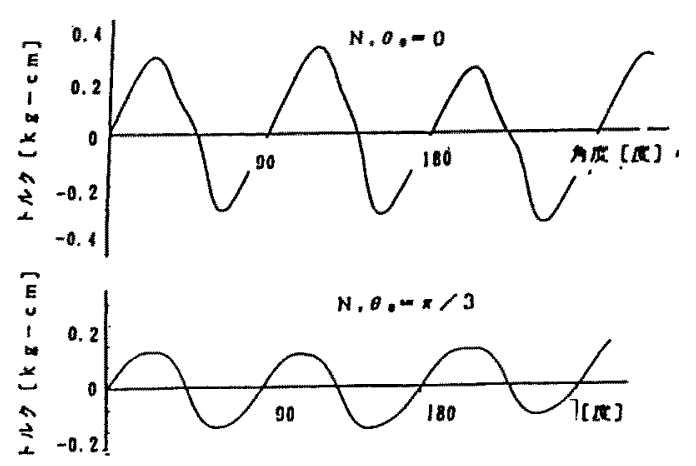

图14.ディテントトルクの実測結果

Fig. 14 Experimental results of detent torque.
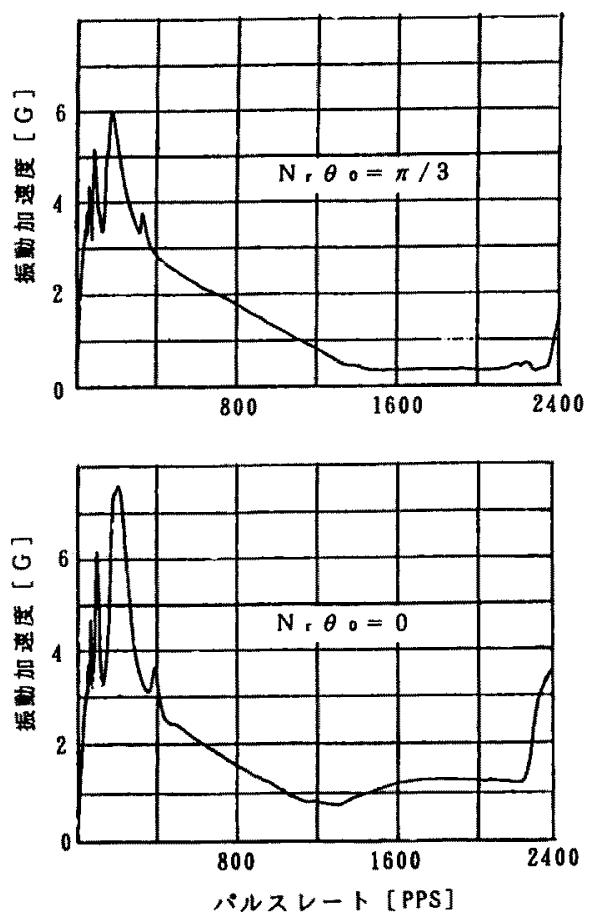

図 15 , 振動特性の実测結果

Fig. 15 Experimental results of vibration characteristics.

にすることにより低速域での共振特性が減少すること、高

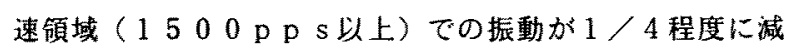
少することが示されている。これはく 2・2〉の解析結果 からも明かなように、高調波磁束に基つく振動トルクが減 少したためと考えられる。

〈4・2〉 マイクロステップ趿時の特性 図 16 は $\mathrm{N}_{\mathrm{r}} \theta_{0}=0$ およびN $\theta_{0}=\pi / 3$ における 16 分割マイク ロステップ駆動時の静止角度誤差（リニアリティ）を示し たものである。同図から $N_{1} \theta_{0}=\pi / 3$ とすることにより リニアリティが改善されていることがわかる。一般にリ二 アリティは前述したトルクー角度特性が正弦波に近いほど 
改善されるため、図16に示された結果は図14k示され たディテントトルクの改善等によるトルク一角度特性の改 善（図14）に基つくものと考えられる。

ステッピングモータはレーザビームプリンタのドラム駆 動の例の如く、定速㽖動に用いられる場合には回転むらが 問題となる。図17は供試 2 相ステッピングモータを種々 の周波数の平衡 2 相正弦波電圧で叹動し、その時生ずる回 転子振動を 2 相誘導速度発電機を用いて変動加速度として 測定したものである。

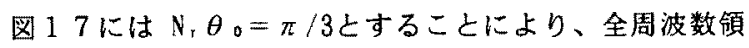
域に亘り、回転変動が極めて小さくなることが示されてい る。
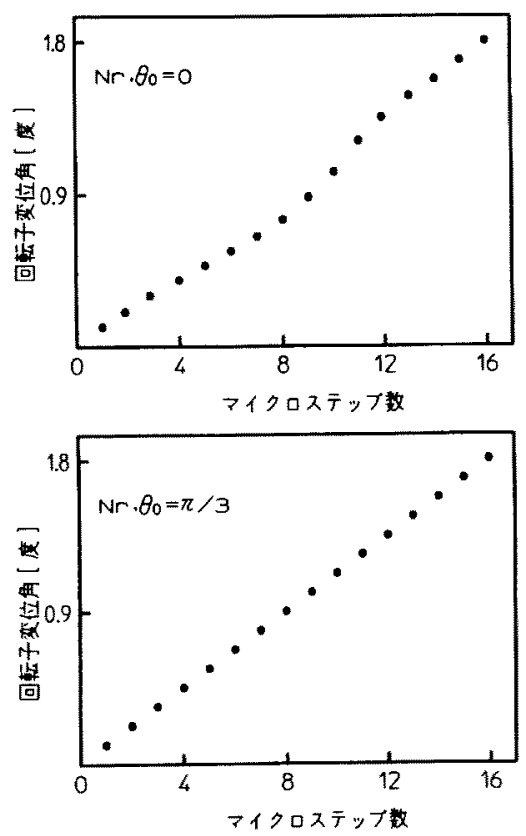

図16.マイクロステップ俚動時のステップ角度 の実測結果

Fig. 16 Experimental results of step accuracy in micro-step drive.

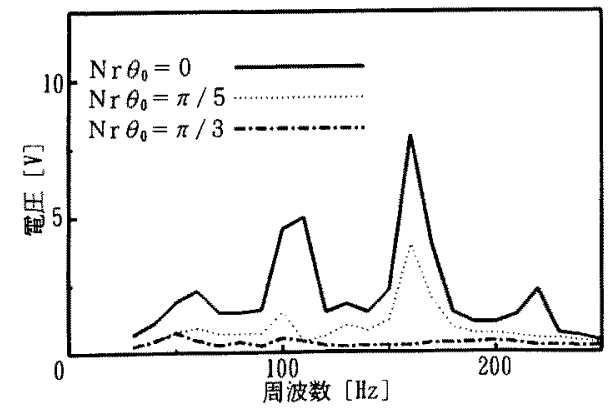

図17.正弦波㪙動時の振動トルクの比較

Fig. 17 Comparison of vibration torque of moters under sinusoidal voltage source.
図18 は変動加速度に基つく速度発電機の出力電圧波形 を示す。同図には出力電任の周波数は励磁周波数の 4 倍と なっていることが示されており、これは先の解析結果(16) 式を裏付けている。

以上の検討結果から本方法は、フルステップ聑動時およ びマイクロステップ駆動時の特性改善に有効であることが わかる。なお、Nｒ。。值は界磁磁柬に基つく巻線誘起 電压の周波数分析結果から選定されることになる。

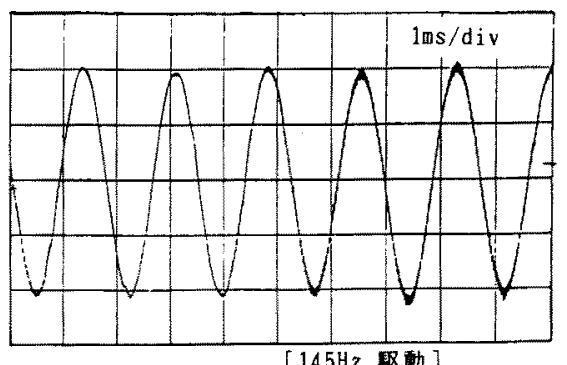

図 18 . 正弦波爽動時の振動トルク波形

Fig. 18 Vibration torque wave of a sample moter under sinusoidal voltage source.

\section{5.むすひ}

八イブリッド形ステッピングモータの界磁磁束に含まれ る高調波分の低減法を提案すると共に、その有効性を確か めた。本低减法は、従来の回転子をそのまま用い、組立の 際に一部変更するだけのもので、製作が容易でありコスト の面でも問題が生じないものである。

本方法により界磁磁束の低減計った結果、

・ステッフネス特性が改善された。

・ティテントトルクが1/2以下に減少した。

・脱出卜ルク特性の低速領域での共振特性が大幅に減少 した。

・静止角度虽差が1/2以下に減少した。

・高速領域での振動が1/4程度に減少した。 またマイクロステップ駆動時においては、

・ステップ角度精度が向上した。

・回転変動が著しく低隇した。

などの結果が示され、本方法がハイブリット形ステッピ ングモータの特性改善に有効であることが明らかになった。 なお、今回は 2 組の回転子をもつような構造の回転子を用 いたか、通常の回転子を用いても回転子の前側と後万側の ヨークををれそれ 2 分して同様の考えを適用すれば特性改 善が期待される。

(平成 6 年 1 月 10 日受付、同 6 年 7 月 5 日再受付)

$$
\text { 文嗝 }
$$

(1) H.D.Chai, et al. : "Effect of Saturation on Step 
Motor Tooth Permiance and Force ", Proc. 11th, Incremental Motion Control Systems and Devices, pp. 223 231 (1982)

(2) T. J. Barned, et, al.: "Finite Element Analysis of Electro-Mechanical devices "Pro. 16th, Incremental Motion Control System and Devices , pp. $275 \sim 296$ (1987)

(3) H. A. F. Ibrahim , "Harmonic Analysis of Stepper Mo ters", Proc. 18th, Incremental Motion Control Sys tem and Devices, pp. 193 200(1989)

(4) H. Dohmeki, et, al. :"Analys is of Harmonic Torque in Stepping Motor" , Proc. 18th, Incremental Motion Control System and Devices ,pp. 225 231(1988)

(5) G. Qishan, et al. : Unifying Approach to the Static Torque of Steppig Motor Structures", Proc. IEE, 124 No. 12, pp1215 1224(1977)

(6) A. Tozune, et,al.: " A Method of Compensation for the Characteristics Reterioration of Hybrid Stepping Moter by Space Harmonic Flux", Small Motor Inter national Conference, (1993-7)

（7）坂本他：「ステッピングモータのマイクロステップ駆
動時の特性改善法」電気学会回転機研究会 R M - 9 3 $-78,67 \sim 75$ (平 $5-10$ )

（8）横塚：「ハイブリッドステッピングモータのステッフ ネス特性のひずみ」電学誌 $\mathrm{B}, 102,661 \sim 66$ 6 (昭 $57-10$ )

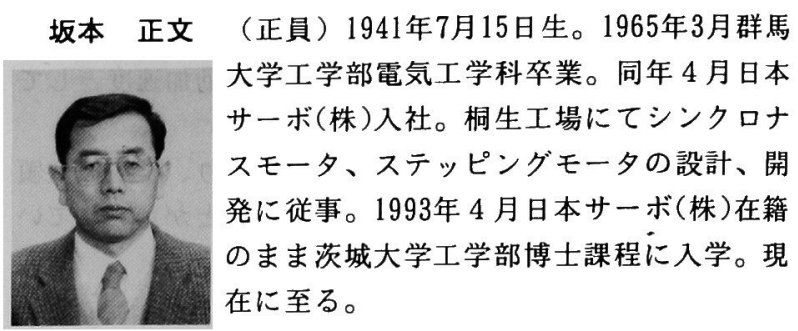

戸恒 明 （正員）1941年7月16日生。1967年群馬大学 大学院修士課程修了同年 4 月三洋電機(株)

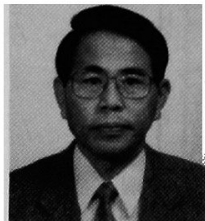
入社。1970年 1 月群馬大学工学部助手、そ の後講師、助教授を経て、1992年 4 月茨城 大学工学部教授、現在に至る。主として制 御機器に関するの研究に従事。工学博士。 電気学会、計測制御学会、I E E E 会員。 